Bond University

Research Repository

\author{
"Reverse Permissibility" in the Renewable Energy Sector \\ Going Beyond the US-India Solar Cells Dispute \\ Ghori, Umair \\ Published in: \\ Asian Journal of International Law \\ DOI: \\ 10.1017/S204425131600028X
}

Link to output in Bond University research repository.

Recommended citation(APA):

Ghori, U. (2018). "Reverse Permissibility" in the Renewable Energy Sector: Going Beyond the US-India Solar Cells Dispute. Asian Journal of International Law, 8(2), 322-349. https://doi.org/10.1017/S204425131600028X

\footnotetext{
General rights

Copyright and moral rights for the publications made accessible in the public portal are retained by the authors and/or other copyright owners and it is a condition of accessing publications that users recognise and abide by the legal requirements associated with these rights.
}

For more information, or if you believe that this document breaches copyright, please contact the Bond University research repository coordinator. 


\title{
"Reverse Permissibility" in Renewable Energy Sector: Going Beyond the US-India Solar Cells Dispute
}

\author{
Umair Hafeez GHORI* \\ Bond University, Australia \\ ughori@bond.edu.au
}

\begin{abstract}
Recent years have witnessed a rise in conflict between WTO Members over the use of state subsidies designed to promote the renewable energy sector. Government subsidies are seen by domestic policymakers as a key catalyst in attracting foreign investment, building capacity and meeting other domestic policy goals. However, subsidies and other state incentivization programmes often carry tradedistorting effects. The article examines the current state of WTO law and jurisprudence on subsidies extended to achieve environmental goals, in particular the Canada-Renewable Energy/Feed in Tariff case and the more recent India-Solar Cells case which higlights the localization problem in the renewable energy sector. The case outcome shows that the WTO continues to maintain the status quo by prioritizing free trade over environmental considerations. The article also discusses the possibility of reform in the GATT/WTO framework for promotion of renewable energy initiatives while maintaining the integrity of the system.
\end{abstract}

\section{INTRODUCTION AND BACKGROUND TO THE DISPUTE}

In late August 2015, the dispute settlement panel established by the World Trade Organization (WTO) confidentially circulated its decision in the much-anticipated case of India-Certain Measures Relating to Solar Cells and Solar Modules (the Panel Report was eventually circulated to the public in February 2016). ${ }^{1}$ At the original version of the article's time of writing, various media resources had begun to report on the outcome of the case and the contents of the confidential interim report. ${ }^{2}$ As per the initial reports, India officially appealed the finding of this case in April 2016. ${ }^{3}$ In the India-Solar Cells case, the complainant (viz. the US) argued that domestic content requirement maintained by India to promote use of solar energy conflicted with its WTO obligations. While the parties will now battle in the Appellate Body where some findings of the panel's decision may be reversed or

\footnotetext{
* LLB (Hons), LLM, PhD. Assistant Professor, Faculty of Law, Bond University. Member, Transnational, International, Comparative Law and Policy [TICLP] Network. I am grateful to Tonya Roberts who provided invaluable and prompt research assistance. The usual disclaimers apply.

${ }^{1}$ WTO Panel Report, India-Certain Measures Relating to Solar Cells and Solar Modules, 24 February 2016, WTO Doc. WT/DS456/R [India-Solar Cells].

${ }^{2}$ See e.g. D Ravi KANTH, Asit Ranjan MISHRA, and Utpal BHASKAR, "WTO Rules Against India in Solar Panels Dispute with the US” LiveMint (27 August 2015), online: LiveMint

<http://www.livemint.com/Politics/11yE8Bz6bgZZ6LhXXlB8eL/WTO-panel-rules-against-India-in-solardispute.html>; Charles PIERSON, "How the US and the WTO Crushed India’s Subsidies for Solar Energy" Counterpunch (28 August 2015), online: Counterpunch <http://www.counterpunch.org/2015/08/28/how-the-usand-the-wto-crushed-indias-subsidies-for-solar-energy/>; Rajesh ROY, “WTO Panel Rules Against India’s Solar Program” The Wall Street Journal (1 September 2015), online: The Wall Street Journal

$<$ http://www.wsj.com/articles/wto-panel-rules-against-indias-solar-program-1441112645>.

${ }^{3}$ See generally, WTO, "Notification of an Appeal by India under Article 16.4 and Article 17 of the Understanding on Rules and Procedures Governing the Settlement of Disputes (DSU), and Under Rule 20(1) of the Working Procedures for Appellate Review”, India-Certain Measures Relating to Solar Cells and Solar Modules, 20 April 2016, WTO Doc. WT/DS456/9; "India Loses Solar Case Against US at WTO; to Appeal” NDTV (28 August 2015), online: NDTV <http://www.ndtv.com/india-news/india-loses-solar-case-against-us-atwto-to-appeal-1211764>; and Michael CRUICKSHANK, "India Loses WTO Case on Solar Panels Suppliers” The Manufacturer (1 September 2015), online: The Manufacturer <http://www.themanufacturer.com/articles/india-loses-wto-case-on-solar-panels-suppliers/>.
} 
modified, the decision clearly highlights larger systemic issues within the WTO, especially with regard to the ability of the WTO Members to pursue domestic development policies using subsidies.

The Indian programme in question, known as the Jawaharlal Nehru National Solar Mission programme (JNNSM), was initiated by the Government of India in early 2010. Briefly, the JNNSM aims to generate an additional 20,000 megawatts of electricity by $2022 .{ }^{4}$ The JNNSM aims to achieve its objective through several phases. Under the JNNSM, entities that develop solar power generation projects (referred to as the Solar Power Developers, abbreviated as SPDs) enter into power purchase agreements (PPAs) with power purchasers (PPs) that are under the control of the Indian Government. The PPs agree to purchase electricity generated by the SPDs solar technology at a fixed, contractually agreed rate. The generated electricity is then sold onwards to distribution utility companies that in turn sell electricity to consumers.

The JNNSM is managed by the Government of India's Ministry of New and Renewable Energy (MNRE). The MNRE oversees two government-owned entities, namely, the National Thermal Power Corporation (NTPC) and the Solar Energy Corporation of India (SECI). ${ }^{5}$ NTPC-owned subsidiary NTPC Vidyut Vyapar Nigam Limited (NNVN) managed Phase I of the JNNSM, including entering into PPAs with SPDs. ${ }^{6}$ During Phase II of the JNNSM, the role was transferred to SECI (which is wholly-owned by the Indian Government and is under the administrative control of the MNRE). ${ }^{7}$

The dispute between India and the US rests on the domestic content requirements (DCRs) that were included in the Guidelines accompanying various Batches within Phase I and II of the JNNSM. The draft Guidelines stipulated that participating SPDs must use solar cells and modules manufactured in India. ${ }^{8}$ The US claim highlighted that in order for an SPD to avail fixed, contractually-agreed rates under the JNNSM, the SPD must ensure compliance with the DCR requirement for solar cells and modules used in Solar Photovoltaic (PV) power plants. ${ }^{9}$ The US claim also highlighted the progressive increase in the DCR requirements over time to include not just solar cells and crystalline silicon solar modules, but also solar thin-film modules. ${ }^{10}$ This expansion in the scope of DCRs was of concern to the US, because US exports of thin-film technology held significant share in the Indian solar PV market as opposed to solar cells and solar modules (where the US exports to India were few). ${ }^{11}$

\footnotetext{
${ }^{4}$ See generally, Government of India, Ministry of New and Renewable Energy, "Scheme / Documents", online: Ministry of New and Renewable Energy <http://www.mnre.gov.in/solar-mission/jnnsm/introduction-2/>.

${ }^{5}$ See NTPC, “NTPC Overview”, online: NTPC < http://www.ntpc.co.in/en/about-us/ntpc-overview>; and Solar Energy Corporation of India, "Introduction”, online: SECI

$<$ http://www.seci.gov.in/content/innerpage/introduction.php>.

${ }^{6}$ WTO Panel Report, supra note 1 at paras. 7.4-5; and EU, "Third Party Written Submission by the European Union”, India-Certain Measures Relating to Solar Cells and Solar Modules, 19 December 2014, WTO Doc. WT/DS456, at paras. 7-8.

${ }^{7}$ Ibid.

${ }^{8}$ See USTR, "First Written Submission of the United States”, India-Certain Measures Relating to Solar Cells and Solar Modules, WTO Doc WT/DS456 (24 October 2014) at paras. 26-8.

${ }^{9}$ The US, for example, cited section 2.5D of the Draft Guidelines for Phase II (Batch 2) of the JNNSM entitled as "Domestic Content Requirement". The relevant provision reads: "Under the DC, the solar cells and modules used in the solar PV power plants must both be made in India” (Ibid., at paras. 26-8, 32). In the earlier Phase I (Batch 1) Guidelines, the US highlighted section 2.5D which explicitly stated that "in case of Solar PV Projects to be selected in the first batch during FY 2010-11, it will be mandatory for Projects based on crystalline silicon technology to use the modules manufactured in India” (Ibid., at para. 30).

${ }^{10}$ See USTR, supra note 8 at para. 33.

${ }^{11}$ See e.g. the discussion in Pierson, supra note 2.
} 
The dispute settlement process was initiated in February 2013 by the US when it requested consultations with India on measures relating to domestic content requirements maintained under the JNNSM. ${ }^{12}$ The US claimed that these measures violated several provisions of GATT and the WTO Agreement on Subsidies and Countervailing Measures (ASCM) and the WTO Agreement on Trade-Related Investment Measures (TRIMS). More specifically, the US claimed that India's measures not only violated the GATT/WTO norms, but also caused impairment or nullification of benefits accruing to the US through the WTO Agreements.

During the course of the proceedings, several countries reserved their third party rights under Article 10 of the WTO Dispute Settlement Understanding (DSU). These third party countries included the EU, Canada, and Japan, who are not only major stakeholders in the international renewable energy market, but whose trade interests also stand to be affected by the outcome of the India-Solar Cells case. ${ }^{13}$ Japan, for example, submitted that as one of the largest producers of solar thin-film technology impacted under the Indian DCRs, it was indirectly affected by the DCR requirement under the JNNSM and therefore, had a "substantial interest". ${ }^{14}$ Japan also pointed out its role as the complainant in the CanadaFeed in Tariff case, the leading WTO "precedent" in the area of renewable energy subsidies to date. ${ }^{15}$ The other third party countries may also be affected indirectly if they have policies akin to the Indian JNNSM programme that require the use of domestic content. Therefore, the decision by the dispute settlement panel and the impending decision by the Appellate Body can potentially have significant repercussions on how WTO Member governments construct their subsidy programmes in relation to renewable energy schemes. ${ }^{16}$ Following the consultation phase, the WTO Dispute Settlement Body (DSB) established a dispute settlement panel in September 2014. The dispute settlement panel issued its interim report to the disputing parties in late August 2015. Originally kept confidential, the report was made public in February 2016. Accordingly, the original draft of this article which was written circa August 2015 took into consideration documents available in the public domain. With the public release of the Panel Report in India-Solar Cells, the references to documents outlining the disputants' arguments have been updated and supplemented with the relevant paragraphs from the Panel Report.

Part I of this article briefly introduces the issues underpinning the question of state support for the development of domestic sectors, and then examines the pertinent arguments in the Canada-Renewable Energy/Feed in Tariffs case (which shares similar issues and questions of law with the India-Solar Cells case). Part II examines the arguments of the parties in the India-Solar Cells case, providing a basis for analysis in Part III of the article. Part IV suggests an alternative approach (entitled "Reverse Permissibility") that may help to resolve the question of state support towards development of domestic renewable energy industries.

\footnotetext{
${ }^{12}$ See generally, Government of India, Ministry of New and Renewable Energy, supra note 4.

${ }^{13}$ WTO records Brazil, Ecuador, Canada, China, Chinese Taipei, EU, Japan, Korea, Malaysia, Norway, Russia Saudi Arabia and Turkey as countries which have reserved their third party rights. See WTO, "dispute settlement - the disputes - DS456”, online: WTO <https://www.wto.org/english/tratop_e/dispu_e/cases_e/ds456_e.htm>.

${ }^{14}$ WTO, "Request to Join Consultations-Communication from Japan”, India-Certain Measures Relating to Solar Cells and Solar Modules, 25 February 2014, WTO Doc WT/DS456/4.

${ }^{15}$ Ibid.

${ }^{16}$ See e.g. comments in Ishita DAS, "Switching off the Sun? The India-US Solar Cells Dispute" Oval Observer Foundation (19 January 2015), online: Oval Observer Foundation <http://ovalobserver.org/switching-off-sunindia-us-solar-cells-dispute/>.
} 


\section{THE QUESTION OF STATE SUPPORT: THE CANADA-RENEWABLE ENERGY/FEED IN TARIFFS CASE}

State-supported development of domestic industries is not a new concept. All developed countries have adopted such measures in the past. However, in the context of the renewable energy sector and its associated industries, state support assumes greater complexity. This is for two reasons.

First, renewable energy producers cannot compete with conventional energy producers due to steep differences in operating costs and business characteristics. ${ }^{17}$ As long as differences exist between conventional and renewable energy generation, the market for renewable energy can only come into existence through government regulation. ${ }^{18}$ In other words, governments' policy decisions to diversify the energy generation base create room for an otherwise non-competitive source of power generation.

The second complication flows from the point in time when the government makes a policy decision to diversify the energy generation base to include power generation through renewable energy. At this point in time, governments often connect the renewable energy sector with domestic allied industries in a bid to create jobs and attract foreign investment into the country. In order to do so, governments offer various incentives and support programmes to local industries and foreign investors. The cornerstone of these support policies is usually an incentivization programme which encourages use of locally-produced components in order for the renewable energy generator to qualify for further benefits, such as competitive powerpurchase tariffs. This is where such policies may fall afoul of GATT/WTO rules on subsidies. The most recent, and perhaps the best, illustration is the Canada-Renewable Energy/Feed in Tariffs case, which underscores the limitations imposed by international trade rules on the development of a renewable energy sector by the WTO Members. ${ }^{19}$

The Canada-Renewable Energy/Feed in Tariffs case assumes greater importance in the present case because it is considered a direct "precedent" in WTO jurisprudence on renewable energy policies. This is illustrated through India's attempts to differentiate Ontario's Feed-In Tariff (FIT) Program from the JNNSM, and the arguments of the US which point out similarities between the two. ${ }^{20}$ The following section examines pertinent arguments made by the Appellate Body in Canada-Renewable Energy/Feed in Tariffs case.

Similar to India, Ontario's FIT Program incentivized electricity producers to use a minimum percentage of domestically-manufactured components in exchange for a fixed, guaranteed rate of power purchase for long-term periods spanning 20-40 years. The FIT Program was challenged by the EU and Japan; both lodged separate disputes but cited similar arguments. The common arguments in both claims were that it violated GATT Article III: 4

\footnotetext{
${ }^{17}$ See e.g. WTO Appellate Body Report, Canada-Measures Affecting the Renewable Energy Generation Sector, 6 May 2013, WTO Doc. WT/DS412/AB/R [Canada—Renewable Energy]; and Canada-Measures Relating to the Feed-in Tariff Program, 6 May 2013, WTO Doc. WT/DS426/AB/R [Canada-Feed in Tariff] at paras. 5.170, 5.174 cited in Rajib PAL, "Has the Appellate Body's Decision in Canada-Renewable Energy/Feed-in Tariff Program Opened the Door for Production Subsidies?” (2014) 17 J Int Economic Law 125 at 128.

${ }^{18}$ WTO Appellate Body Report, supra note 17 at para. 5.175.

${ }^{19}$ See e.g. Leah STOKES, “The Politics of Renewable Energy Policies: The Case of Feed-in Tariffs in Ontario, Canada” (2013) 56 Energy Policy 490 at 495.

${ }^{20}$ See e.g. USTR, “Second Written Submission of the United States”, India-Certain Measures Relating to Solar Cells and Solar Modules, 11 March 2015, WTO Doc. WT/DS456 at paras. 18-23, 28-32.
} 
(National Treatment) and Article 2.1 of the TRIMS Agreement. ${ }^{21}$ Furthermore, by providing the benefit of guaranteed tariffs, the Government of Ontario essentially extended prohibited subsidies that effectively constituted import substitution, thus violating Articles 3.1(b) and 3.2 of the WTO ASCM. ${ }^{22}$ Both the EU and Japan made the prohibited subsidy argument the cornerstone of their complaint since a finding under Article 4.7 of the ASCM would have meant that the dispute settlement panel will recommend immediate withdrawal of the offending measure by the violating Member. ${ }^{23}$

The Appellate Body, in its decision, upheld the earlier findings by the panel that the feed in tariffs scheme was in violation of GATT Article III: 4 and Article 2.1 of the TRIMS Agreement. ${ }^{24}$ Earlier, the panel in Canada-Renewable Energy/Feed in Tariffs grappled with the question whether various feed in-tariff schemes operated by Ontario were inconsistent with Article 2.1 of the TRIMS Agreement by virtue of "being inconsistent with the national treatment obligation provided for in Article III: 4 of the GATT 1994." 25 The panel in its analysis acknowledged reliance placed by Canada upon Article III: 8(a) of the GATT 1994, which would have served "to remove the challenged measures from the scope of Article III: 4 of the GATT 1994, and thereby also the disciplines found in Article 2.1 of the TRIMs Agreement." ${ }^{26}$ Article III: 8(a) provides a "way out” for governments of the WTO Members in extending National Treatment to other WTO Members. The effect of Article III: 8(a) is that National Treatment obligations would not be applicable to any laws, regulations, or requirements pertaining to government procurement of products purchased for governmental purposes and not for any commercial resale. ${ }^{27}$ Additionally, Article 2.2 of the TRIMS Agreement informs WTO Members about the existence of the Illustrative List contained within the Annex of the TRIMS Agreement. Article 2.2 aids in interpreting Article 2.1 prohibition and the GATT National Treatment obligation contained within Article III: 4.

Essentially what Article 2.2 is stating is that any TRIMs described in the Illustrative List of the Annex to the TRIMs Agreement is considered inconsistent with WTO Members' obligations under Article III: 4. Within the Illustrative List, Paragraph 1(a) provides that:

1. TRIMs that are inconsistent with the obligation of national treatment provided for in paragraph 4 of Article III of GATT 1994 include those which are mandatory or enforceable under domestic law or under administrative rulings, or compliance with which is necessary to obtain an advantage, and which require:

(a) the purchase or use by an enterprise of products of domestic origin or from any domestic source, whether specified in terms of particular products, in terms of volume or value of products, or in terms of a proportion of volume or value of its local production; (emphasis added)

Therefore, on a combined reading of the aforementioned provisions, the task before the panel was to determine, firstly, whether Canada could rely upon Article III: 8(a) of the GATT to escape the application of Article 2.1 of the TRIMS Agreement; and if not, whether the measures challenged by the EU and Japan were the ones covered under Paragraph 1(a) of the Illustrative List. The panel's finding was that Canada failed to establish its reliance on Article III: 8(a) of the GATT because the procurement of electricity under various feed-in tariff

\footnotetext{
${ }^{21}$ See WTO Panel Report, Canada-Measures Affecting the Renewable Energy Generation Sector, 19 December 2012, WTO Doc. WT/DS412/R [Canada-Renewable Energy]; and Canada-Measures Relating to the Feed-in Tariff Program, 19 December 2012, WTO Doc. WT/DS426/R [Canada-Feed in Tariff] at paras. 3.1, 3.4.

${ }^{22}$ Ibid.

${ }^{23}$ Ibid., at paras. 3.2(a), 3.5(a).

${ }^{24}$ WTO Appellate Body Report, supra note 17 at para. 5.85 .

${ }^{25}$ WTO Panel Report, supra note 21 at para. 7.107.

${ }^{26}$ Ibid.

${ }^{27}$ Ibid., at para. 7.118 .
} 
schemes was pursuant to commercial resale of electricity. ${ }^{28}$ The panel also concluded that the measures challenged by the EU and Japan fell within the coverage of Paragraph 1(a) of the Illustrative List and hence, Canada was in violation of Article 2.1 of the TRIMS Agreement and Article III: 4 of the GATT. ${ }^{29}$

Upon appeal, the Appellate Body moved beyond the panel decision on derogation from Article III: 8(a). The panel had earlier concluded that Ontario's purchase of electricity was well within the ambit of Article III: 8(a) because the solar and wind power generation equipment was needed to produce electricity. ${ }^{30}$ That would have meant that Ontario's DCR requirement and consequent purchase of electricity generated would have amounted to government procurement, thereby bypassing the application of GATT Article III: 4 and TRIMS Article 2:1. According to the panel, there was sufficient evidence to establish a "close relationship" between products (i.e. power generation equipment) affected by the DCR and the product procured therefrom (i.e. electricity). ${ }^{31}$

The Appellate Body was not convinced. The Appellate Body decided that there was insufficient connection between the DCR under Ontario's programme and the consequent purchase of electricity so as to bring the said DCRs within the scope of Article III: 8(a). ${ }^{32}$ The Appellate Body observed that the product being procured by Ontario was electricity while the product that was the subject of discrimination by way of its origin was power generation equipment. ${ }^{33}$ Hence, the Appellate Body concluded that these two products were not in a competitive relationship. ${ }^{34}$ The Appellate Body also clarified that, in determining the nature of a competitive relationship between associated products, consideration must be given to "inputs and processes" that are employed to produce a particular product. ${ }^{35}$

In addition to Article III: 8(a) derogation, another issue at appeal before the Appellate Body was the claim by the EU and Japan that the feed-in tariff scheme operated by Ontario amounted to a prohibited subsidy under Article 1.1 of the ASCM. Here the line of reasoning differs from the arguments adopted in the case of a derogation claim under Article III: 8(a). Article 1.1 of the ASCM provides the test to determine a provision of subsidy. This test was explained by the Appellate Body in Canada-Aircraft ${ }^{36}$ as requiring either a financial contribution or direct transfer of funds (or purchase of goods); [and that] benefit is conferred as a result (emphasis added).

The Appellate Body further explained that coverage of subparagraphs (i) and (iii) of Article 1.1(a)(1) is not mutually exclusive. ${ }^{37}$ Here, the Appellate Body placed reliance on an earlier Appellate Body decision in US-Large Civil Aircraft, wherein it was observed at para. 613 that Article 1.1(a)(1) did not explicitly "spell out the intended relationship between the constituent subparagraphs." 38

\footnotetext{
${ }^{28}$ Ibid., at para. 7.152 .

${ }^{29}$ Ibid., at para. 7.167 .

${ }^{30}$ Ibid., at para. 7.127.

${ }^{31}$ Ibid.

${ }^{32}$ WTO Appellate Body Report, supra note 17 at para. 5.78.

${ }^{33}$ Ibid., at para. 5.79 .

${ }^{34}$ Ibid., at para. 5.79.

${ }^{35}$ Ibid., at para. 5.63 .

${ }^{36}$ See generally, WTO Appellate Body Report, Canada-Measures Affecting the Export of Civilian Aircraft, 2

August 1999, WTO Doc. WT/DS70/AB/R [Canada-Aircraft].

${ }^{37}$ WTO Appellate Body Report, supra note 17 at para. 5.119.

${ }^{38}$ Ibid.
} 
The Appellate Body was of the view that the EU and Japan had failed in establishing that the feed-in tariff scheme qualified as a prohibited subsidy within the purview of Article 1.1 of the ASCM. The implication of this finding is that claims under Article 3.1 and 3.2 (prohibited subsidy) essentially failed because a positive finding under Article 1 is a prerequisite for a finding of a prohibited subsidy.

The Appellate Body agreed with the panel finding that the feed-in tariff scheme did provide financial contribution within the purview of Article 1.1(a)(1)(iii) of the ASCM. ${ }^{39}$ This was because the Government of Ontario had purchased electricity generated under various feed-in tariff schemes. ${ }^{40}$ However, the Appellate Body held that the second limb of Article 1 of the ASCM (i.e. Article 1.1(b)) conferring a benefit was not satisfied. ${ }^{41}$ In reaching this decision, the Appellate Body seemed to be saying that when governments decide to diversify the energy mix within a country leading to the creation of a new market as a consequence, and this market would not otherwise have existed without governmental action/incentivization, this cannot be termed as conferrng a "benefit" within the meaning of Article 1.1(b) of the ASCM. ${ }^{42}$ The Appellate Body reasoned: "Where a government creates a market, it cannot be said that the government intervention distorts the market, as there would not be a market if the government had not created it." 43

The Appellate Body continued to say that the creation of markets by a government does not amount to extending subsidies within the meaning of the ASCM. ${ }^{44}$ However, government interventions in markets that already exist may amount to subsidies "when they take the form of a financial contribution, or income or price support, and confer a benefit to specific enterprises or industries." 45

Unfortunately, the Appellate Body's decision effectively stops at this point because it was unable to complete the analysis on whether the challenged measures conferred a benefit under Article 1.1(b) of the ASCM and whether Canada acted contrary to Articles 3.1(b) and 3.2 of the ASCM. The Appellate Body declared that it found it "impossible to complete the legal analysis due to insufficient factual findings in the panel report or a lack of undisputed facts on the panel record." ${ }^{46}$ The Appellate Body also cited "complexity of the issues, the absence of full exploration of the issues before the panel, and, consequently, considerations for parties' due process rights" as further reasons behind the non-completion of the analysis on conferral of benefit. ${ }^{47}$

\section{THE CURRENT DISPUTE: INDIA—SOLAR CELLS}

India-Solar Cells is a clear case of government policy intervention that enables the renewable energy sector to advance. In addition to diversification in energy generation, governmental intervention obviously creates fertile grounds for investment and business opportunities. In the absence of any government intervention, the renewable energy sector

\footnotetext{
${ }^{39}$ Ibid., at para. 5.128.

${ }^{40}$ Ibid.

${ }^{41}$ Ibid., at paras. 5.246, 6.1(b)(i). In doing so, the Appellate Body reversed the Panel's finding, in paragraphs

7.328(ii) and 8.7 of the EU Panel Report (see WTO Appellate Body Report, supra note 17 at para. 6.1(b)(i)).

42 Ibid., at para. 5.175 .

${ }^{43}$ Ibid., at para. 5.188.

${ }^{44}$ Ibid.

${ }^{45}$ Ibid.

${ }^{46}$ Ibid., at para. 5.224.

${ }^{47}$ Ibid.
} 
would not be able to compete with traditional power generators. ${ }^{48}$ Essentially, the dispute between the US and Indian Governments centers around the use of governmental measures to promote a sector which may invariably conflict with multilateral trade commitments under the GATT/WTO.

The US arguments points to, and challenges, such governmental measures adopted by India that aim to increase the use of solar PV technology in generating electricity. The measures in question are the DCR requirements that were found in various stages of the JNNSM (see discussion above). The US argued that India's DCRs breached GATT Article III: 4 and TRIMS Article 2.1, because the DCRs "modify the conditions of competition in favour of cells and modules made in India to the detriment of imported equipment in violation of Article III: 4 of the GATT 1994." 49 The US specifically states that the DCRs operate selectively to exclude imported solar cells and modules from certain projects under the JNNSM while allowing the use of domestically manufactured cells and modules in all projects under the JNNSM. ${ }^{50}$ The US further claimed that the Indian measures breached Articles 3.1(b) as well as 3.2 of the ASCM, which provides subsidies contingent on import substitution. The US also invoked Articles 5(c), 6.3(a), and 6.3(c) of the ASCM, citing adverse effects on US trade interests through the displacement or hindrance of US exports of solar cells and modules to India. ${ }^{51}$

\section{A. GATT Article III:8 Derogation}

Predictably, India attempted to provide a defence of its measures under GATT Article III: 8 derogation along similar lines to Canada in the earlier Canada-Renewable Energy/Feed in Tariff case. Furthermore, India defended its measures citing various general exceptions under GATT Article XX (d) and (j). With this background in mind, this article now summarizes arguments of the disputing parties (and third parties, where relevant) along with the Panel's analysis.

At the outset, India made an admission that the DCRs in question qualify under Paragraph 1(a) of the Illustrative List of the TRIMS Agreement subject to the finding that they are held to be inconsistent with Article III: 4 of the GATT $1994 .^{52}$ It seems that India's strategy was to limit the case to GATT Article III: 4 by watering down the importance of Articles 2.1 and 2.2 of the TRIMS Agreement and the Illustrative list. By limiting the analysis and the defence of its measures, India's strategy appears to utilise the escape valve under GATT Article III: 8(a) derogation which constitutes an exception to the GATT Article III: 4.

In hindsight, however, this strategy proved fatal to the Indian defence in India-Solar Cells case. The US fully exploited this concession by citing the Canada-Renewable Energy/Feed in Tariff judgment, where the Appellate Body noted that any measure that falls within the

\footnotetext{
${ }^{48}$ See e.g. discussion of the investment and transaction cost cycle with reference to wind energy sector in developing countries in Umair GHORI, "Risky Winds: Investing in Wind Energy Projects in Pakistan” (2012) 30(2) J.Energy Nat. Resources \& Envtl L. 129 at 153-6; see also the discussion in Pal, supra note 17 at 128-31; and Stokes, supra note 19 at 495.

${ }^{49}$ See WTO Panel Report, supra note 1 at para. 7.39; see also, USTR, "Second Opening Statement of the United States”, India-Certain Measures Relating to Solar Cells and Solar Modules, 28 April 2015, WTO Doc. WT/DS456 at paras. 2, 4; and USTR, supra note 8 at paras. 26-33.

${ }^{50}$ USTR, Ibid at para. 4; see also USTR, supra note 8 at paras. 31-3.

${ }^{51}$ See WTO Panel Report, supra note 1 at paras. 7.50-1; see also WTO, "Request for Consultations by the United States”, India-Certain Measures Relating to Solar Cells and Solar Modules, 11 February 2013, WTO Doc. WT/DS456/1 at 2.

${ }^{52}$ See WTO Panel Report, supra note 1 at paras. 7.42, 7.44; see also, India’s response to Panel Question No. 2 (b) referred to by USTR, supra note 20 at para. 8 .
} 
meaning of Paragraph 1(a) of the Illustrative List automatically becomes inconsistent with Article III: 4 of the GATT (see arguments in the preceding section). ${ }^{53}$ The US had initially argued for Article III: 4 of the GATT to be reviewed first, but during the course of proceedings was found to lean towards the view that violation of Article 2.1 of the TRIMS Agreement is contingent on finding of a violation of GATT Article III: $4{ }^{54}$ The Panel observed that there are divergent views on the sequencing issue not only by the disputants but also by the third parties. ${ }^{55}$ The EU, for example, claimed that Articles 2.1 and 2.2 of the TRIMS agreement along with the Illustrative List is the more specific provision, therefore, should be applied first. ${ }^{56}$ The EU was of the view that if analysis under Articles 2.1 and 2.2 of the TRIMS agreement is conducted first, "subsequent analysis of Article III of the GATT 1994 will naturally follow." ${ }^{57}$ Canada and Japan disagreed with this approach suggested by the EU. Japan cited conduct of past panels which began their analysis from GATT Article III: 4 while considering TRIMS and GATT 1994 claims simulataenously. ${ }^{58}$ The Panel in its response referred to previous Panel Reports in EC-Bananas III, Indonesia-Autos, Canada-Autos and India-Autos and acknowledged the variance in past panels' treatment of this issue. ${ }^{59}$ However, the Panel explained that the issue in the current dispute is not about sequencing. Rather, the question is whether measures falling within the purview of paragraph 1(a) of the TRIMs Illustrative List are inconsistent with Article III: 4 of the GATT 1994. ${ }^{60}$ The Panel was of the view that, if the measures fall within paragraph 1(a) of the TRIMS Illustrative List, no additional analysis of Article III: 4 of the GATT is needed. ${ }^{61}$

In order to resolve this issue, the Panel referred to the Canada-Renewable Energy/Feed in Tariff case, the "unambiguous wording of Article 2.2", the TRIMs Illustrative List, and noted that the chapeau of Paragraph 1 of the Illustrative List repeats the same language as Article 2.2 of the TRIMs Agreement. ${ }^{62}$ Therefore, any measure that falls within Paragraph 1(a) of the Illustrative List will necessarily be inconsistent with GATT Article III: $4 .^{63}$ The Panel also refused to accept India's argument, drawn from the Canada-Renewable Energy/Feed in Tariff case, that Article 2.2 and the Illustrative List clarify to which TRIMs the general obligation in Article 2.1 applies. ${ }^{64}$ India claimed before the Panel that Article 2.2 and the Illustrative List only serve to provide examples of measures that are subject to the obligations within Article 2.1 of the TRIMS Agreement. ${ }^{65}$ This view would have meant that any measure that fell within Paragraph 1(a) of the Illustrative List will only be an "initial trigger" for obligations under Article 2.1 of the TRIMs Agreement, and that a further assessment under GATT Article III: 4 would be required. ${ }^{66}$ In responding to this argument, the Panel relied on the principle of effet utile, which provides that any party interpreting an international treaty would not be free to adopt a meaning that reduces parts of the treaties as redundant. ${ }^{67}$ The Panel queried India's interpretation and declared that such an approach is difficult to reconcile

\footnotetext{
${ }^{53}$ See USTR, supra note 20 at para. 8.

${ }^{54}$ See WTO, supra note 1 at foonote 219.

${ }^{55}$ Ibid., at para. 7.45 .

${ }^{56}$ Ibid.

${ }^{57}$ Ibid.

${ }^{58}$ Ibid.

${ }^{59}$ Ibid., at footnotes 145, 146.

${ }^{60}$ Ibid., at para. 7.46 .

${ }^{61}$ Ibid.

62 Ibid., at para. 7.47 .

${ }^{63}$ Ibid., at para. 7.47, citing Appellate Body's arguments in Canada-Renewable Energy/Feed in Tariff case (see WTO Appellate Body Report, supra note 17 at paras. 5.24 \& 4.103).

${ }^{64}$ Ibid., at para. 7.51.

${ }^{65}$ Ibid.

${ }^{66}$ Ibid.

${ }^{67}$ Ibid., at para. 7.52.
} 
given the plain language of Article 2.2 and the chapeau of Paragraph 1 of the TRIMs Illustrative List. ${ }^{68}$ Accordingly, the Panel went on to hold that measures falling within Paragraph 1(a) of the TRIMs Illustrative List are automatically inconsistent with GATT Article III: 4 and thus do not require a separate analysis. ${ }^{69}$ The Panel specifically analysed the Indian DCRs and concluded that these measures incentivized use of locally manufactured goods in exchange of long term guaranteed tariff rate for SPDs that utilized them. ${ }^{70}$ Therefore, the Panel held that such measures were not only in violation of TRIMS Agreement, but also accorded less favorable treatment to imported like products under GATT Article III: $4 .^{71}$ Having concluded its analysis to the first major issue, the Panel noted that its conclusion does not prejudice any further analysis on GATT Article III: 8(a) derogation ${ }^{72}$ which formed an important part of India's defence.

As noted above, GATT Article III: 8(a) is an exception to the application of GATT Article III: 4. GATT Article III: 8 derogation is applicable only where the imported product (that is the target of discrimination) is in competitive relationship with the product being purchased (this was clarified in the Canada-Renewable Energy/Feed in Tariff case). Therefore, India had to convince the Panel that the conditions for derogation were met. This, in turn, meant determining the issue of whether the Government of India was purchasing solar modules or purchasing electricity.

The overall Indian argument was that the derogation under GATT Article III:8(a) is applicable to the DCR measures in question and therefore, the DCR measures are not inconsistent with GATT Article III:4 or Article 2.1 of the TRIMs Agreement. ${ }^{73}$ In other words, the Government of India, through its policies, was actually procuring solar cells and modules because it is purchasing the electricity generated therefrom. ${ }^{74}$ The US opposed this argument by referring to the Appellate Body report in Canada-Renewable Energy/Feed in Tariff case wherein it was held that there was insufficient connection between the DCRs and electricity generated for Article III: 8(a) requirement to be met. ${ }^{75}$ Therefore, the US argument was that the derogation for government procurement under Article III: 8 would not be applicable to the DCRs because the government was essentially procuring electricity while the products facing discrimination were renewable energy equipment. ${ }^{76}$

\section{B. Attempts to Distinguish the Canada-Renewable Energy/Feed in Tariff case}

India adopted a novel approach to avoid implications of similar findings in CanadaRenewable Energy/Feed in Tariff. India attempted to exploit the flexibility in the interpretation of Article III: 8(a) by terming the solar panel and modules as "integral input", while products such as inverters and electrical wiring were termed as "ancillary." 77 This would have allowed India to claim equal treatment between the procured product and the discriminated product and introduce a further ground for distinguishing DCRs under JNNSM

\footnotetext{
${ }^{68}$ Ibid.

${ }^{69}$ Ibid., at para. 7.54 .

${ }^{70}$ Ibid., at paras. $7.55-73$.

${ }^{71}$ Ibid., at paras. 7.74-99.

${ }^{72}$ Ibid., at para. 7.54 (see footnote 168).

${ }^{73}$ Ibid., at para. 7.101.

${ }^{74}$ See WTO Panel Report, supra note 1 at paras. 7.101, 7.108, 7.109-10 \& 7.114; see also, India’s First Written

Submission, paragraph 114 referred to by USTR, supra note 20 at para. 14; and USTR, supra note 20 at para. 16.

${ }^{75}$ See WTO Panel Report , supra note 1 at para. 7.154; and WTO Appellate Body Report, supra note 17 at paras. 5.76-8.

${ }^{76}$ See WTO Panel Report , supra note 1 at paras. 7.142 \& 7.165; and WTO Appellate Body Report, supra note 17, at paras. 5.76, 5.79 .

${ }^{77}$ See WTO Panel Report, supra note 1 at paras. 7.109, 7.124, 7.127 (see, in particular, footnote 320).
} 
and Ontario's FIT Program. ${ }^{78}$ In its arguments, India referred to the Appellate Body's observation in Canada-Renewable Energy/Feed in Tariff that a "competitive relationship between products may require consideration of inputs and processes of production used to produce the product." ${ }^{79}$ In essence, India's argument here was that discrimination against imported products can be covered under Article III: 8(a) derogation, provided that the product being discriminated is an integral input for production of the product that is eventually procured by the government. ${ }^{80}$

The US opposed the Indian argument of terming solar panels and modules as integral inputs. Instead, the US claimed that solar panels and modules are capital equipment which are not "consumed" or "incorporated" in the power generation process. ${ }^{81}$ The US was of the view that the governmental agencies purchased electricity generated by the SPDs but not the solar cells and modules, since those remained the property of the SPD. ${ }^{82}$

In addition to the above, India attempted to differentiate the DCRs under Ontario's FIT Program with the DCRs under JNNSM. In particular, India argued that the focus of the first two phases of the JNNSM was on solar power generation using Indian origin solar cells and modules. ${ }^{83}$ India explained that the requirements under the JNNSM sought to "procure solar cells and modules that result in solar power generation." ${ }^{84}$ This, according to India, was different from the FIT Program in Canada-Renewable Energy/Feed in Tariff, where the focus rested upon domestic content in a set of designated activities of a power plant and not on the generation of electricity by that plant. ${ }^{85}$ The US dismissed the Indian arguments attempting to distinguish the DCRs under JNNSM and the feed-in tariff under Ontario'sFIT Program. The US termed the DCRs under both programmes as "functionally identical" and that both required SPDs to "purchase or use domestically sourced renewable energy equipment." 86 The US argument was based on the Appellate Body's observation in CanadaRenewable Energy/Feed in Tariff that the electricity purchased by Ontario was not in competition with the renewable energy equipment purchased by the SPDs. ${ }^{87}$ Therefore, any minor differences between JNNSM and Ontario's FIT Program were inconsequential in the application of the Appellate Body's observation in Canada-Renewable Energy/Feed in Tariff to India-Solar Cells. ${ }^{88}$

During the Panel proceedings, the EU (one of the complainants in Canada-Renewable Energy/Feed in Tariff) supported the US stance in India-Solar Cells. The EU stated that:

"The crux of the matter is whether the products are in a competitive relationship, not whether they are somehow related. To hold otherwise would in effect, allow discrimination by proxy: Members could freely rely on contractors to breach their national treatment obligations for them, as long as the product they are procuring is somehow connected to a favoured domestic product, such as a raw material or

\footnotetext{
${ }^{78}$ See WTO Panel Report, supra note 1 at paras. 7.109 \& 7.114; and India’s response to Panel Question No. 19, paragraphs 2-3 referred to by USTR, supra note 20 at paras. 17-8, 28-9.

${ }^{79}$ See WTO Panel Report, supra note 1 at para. 7.117; and WTO Appellate Body Report, supra note 17 at para.

5.63 quoted in USTR, supra note 20 at para. 18.

${ }^{80}$ See WTO Panel Report, supra note 1 at para. 7.117.

${ }^{81}$ See WTO Panel Report, supra note 1 at para. 7.121; and USTR, supra note 20 at paras. 17-20.

${ }^{82}$ See USTR, Ibid at para. 20.

${ }^{83}$ See WTO Panel Report, supra note 1 at para. 7.114; and India’s First Written Submission, paragraph 112 referred to by USTR, supra note 20 at para. 23.

${ }^{84}$ See WTO Panel Report, Ibid.

${ }^{85}$ Ibid.

${ }^{86}$ USTR, supra note 20 at paras. 22, 28.

${ }^{87}$ Ibid., at para. 21.

${ }^{88}$ Ibid.
} 
another input. This would turn Article III: 8(a) into something of a Trojan horse for the rest of Article III."89

Therefore, the US (and by implication, the EU) have argued that the Indian DCRs at cause are similar to Ontario's DCR under the FIT Program. Both schemes required SPDs and renewable energy producers to source their cells and modules locally. In both cases, the governmental agencies were procuring electricity rather than the components such as cells and modules. ${ }^{90}$ Hence, like Ontario's failed defence of its feed-in tariff scheme, India's defence of the DCRs under JNNSM must fail too.

The Panel in its analysis rejected India's dual argument under Article III: 8(a) that solar cells and modules cannot be treated as distinct from solar power and that by purchasing power generated from cells and modules, the Indian Government is actually procuring cells and modules. ${ }^{91}$ The Panel in its reasoning referred to the Appellate Body report in CanadaRenewable Energy/Feed in Tariff, wherein the Appellate Body termed the connection between generation equipment and the electricity generated therefrom as "the dispositive factor regarding the applicability of Article III: 8(a)." ${ }^{92}$ The Panel also rejected the argument put forward by India that the purchase price of electricity paid by the governmental agencies at the power procurement stage included the price of solar cells and modules. The Panel pointed out that, as the Indian DCRs require the SPDs to purchase solar cells and modules, the findings in Canada-Renewable Energy/Feed in Tariff cannot therefore be distinguished in any way so as to enable India to avail the derogation under Article III: 8(a). ${ }^{93}$ The Panel further termed the Indian DCRs as laws governing the procurement of electricity in that they operate to impose conditions for various processes such as bidding eligibility, participation in the power projects, and the use of domestically manufactured cells and modules. ${ }^{94}$ Thus, the implication was that the SPD can only generate electricity which will be the subject of government procurement if the prescribed conditions under the DCRs are met.

India further argued that purchase of electricity generated by the SPDs were for the governmental purpose of promoting ecologically sustainable power generation. ${ }^{95}$ This function, India claimed, must be viewed from the context of economic development challenges and the needs of its population. ${ }^{96}$ The most interesting response to this claim came not from the US (the complainant) but from Japan (a third party in the case). Japan argued that India does not need to purchase solar power in order to ensure availability of affordable solar power to its population or to ensure non-dependency on imported solar cells and modules. ${ }^{97}$ Essentially, Japan's argument was that the Indian Government had the option to purchase electricity generated through solar power, and that it was entirely possible to achieve aims that India cited as justification without violating GATT/WTO norms. The Panel in its response to India's aforementioned argument did not settle the issue. It did, however, cite the Appellate Body's treatment of "government procurement" in Canada-Renewable Energy/Feed in Tariff, wherein the concept was defined as the purchase of goods or services "for the use of government, consumed by government, or provided by government to recipients in the discharge of its public functions." 98

\footnotetext{
${ }^{89}$ See WTO Panel Report, supra note 1 at para. 7.131; and EU, supra note 6 at para. 38.

${ }^{90}$ See WTO Panel Report, supra note 1 at para. 7.122; and USTR, supra note 20 at para. 32.

${ }^{91}$ WTO Panel Report, supra note 1 at para. 7.128.

92 Ibid., at para. 7.127.

${ }^{93}$ Ibid., at para. 7.129.

${ }^{94}$ Ibid., at para. 7.145.

95 Ibid., at para. 7.153 .

${ }^{96}$ Ibid.

${ }^{97}$ Ibid., at para. 7.155.

${ }^{98}$ Ibid., at para. 7.156 .
} 
The Panel also noted that the Indian Government's aim was a composite of governmental purpose and public functions, whereby the Government of India was procuring electricity and then distributing it as part of its public function. ${ }^{99}$ To this end, India cited various arguments from the role of the state in countering crippling energy deficits to United Nations instruments that mandate the role of the state in guaranteeing access to energy. ${ }^{100}$ Furthermore, India claimed that governmental agencies such as SECI and NVVN do not have a commercial motive in the resale process, and merely act as intermediaries between the SPDs and the distribution companies which conduct onward sale to electricity consumers. ${ }^{101}$

In addition to the above arguments, India cited additional arguments under GATT Article $\mathrm{XX}(\mathrm{d})$ and (j) to justify the JNNSM. GATT Article XX lays down general exceptions that are recognized derogations from the GATT/WTO obligations that WTO Members owe under the GATT/WTO framework.

\section{Exception under GATT Article XX (d)}

Exception (d) of GATT Article XX covers measures that are necessary to secure compliance with domestic laws or regulations that are not inconsistent with the GATT. The wording of exception (d) has been further elaborated on by the WTO Appellate Body in two cases: Korea-Various Measures on Beef ${ }^{102}$ and Mexico-Taxes on Soft Drinks. ${ }^{103}$ In KoreaVarious Measures on Beef, the Appellate Body clarified that application of Exception (d) is based two elements that the measure in question "must be designed to ensure compliance with domestic law" that are not in conflict with GATT and that the measures are necessary to ensure compliance thereof. ${ }^{104}$

The Appellate Body further elaborated that the laws and regulations that have to be enforced must either form part of the domestic legal system of a WTO Member as legislation, or an international treaty or agreement that has a direct application within the domestic legal system of a WTO Member. ${ }^{105}$

India took the argument that the DCRs at issue were essential in ensuring compliance by India with its obligations under domestic and international law. ${ }^{106}$ To this end, India cited several pieces of domestic legislation and international declarations on climate change/environmental policy (namely the UN Framework Convention on Climate Change (UNFCCC), UN Conference on Enviornment and Development 1992, Convention on Biological Diversity, the Government of India's National Action Plan on Climate Change, the Electricty Act, the National Electrity Policy and the National Electricty Policy). India claimed that various treaties and international instruments on environmental conservation have a "direct" effect within India's polity and therefore, the Government of India is bound to implement these treaty instruments. ${ }^{107}$ Hence, the Indian argument was that the DCRs are

\footnotetext{
${ }^{99}$ Ibid., at para. 7.157.

${ }^{100}$ Ibid., at para. 7.161.

101 Ibid., at para. 7.164.

102 WTO Appellate Body Report, Korea-Measures Affecting Imports of Fresh, Chilled and Frozen Beef, 31 July 2000, WTO Doc. WT/DS161/AB/R.

${ }^{103}$ WTO Appellate Body Report, Mexico-Tax Measures on Soft Drinks and Other Beverages, 6 March 2006 , WTO Doc. WT/DS308/AB/R.

${ }^{104}$ WTO Appellate Body Report , supra note 102 at para. 157.

${ }^{105}$ WTO Appellate Body Report , supra note 103 at paras. 69, 79.

${ }^{106}$ See WTO Panel Report, supra note 1 at paras. 7.268-76; and paragraphs 240, 255, and 260 of India's First Written Submission referred to by USTR, supra note 20 at para. 51.

107 See WTO Panel Report, supra note 1 at paras. 7.294-7.
} 
necessary for the Government of India to secure its own compliance. The US countered this argument by pointing out that India had not argued that the cited instruments were laws that were enforceable against persons falling within the jurisdiction of India. ${ }^{108}$ Instead, the instruments cited by India were legal obligations on the Government of India itself. ${ }^{109}$ The US viewed Article XX(d) as:

"not the vehicle for a Member to achieve compliance by its own government... As this type of selfenforcement is the only enforcement cited by India, it has not satisfied the requirements for invoking Article XX (d) to justify the DCRs at issue.” 110

The US further argued that the laws and international obligations cited by India do not mention or specify the imposition of the DCRs. ${ }^{111}$ The policy documents and international declarations, the US argued, were so broad that these would not qualify as laws or regulations requiring compliance within the meaning of Article $\mathrm{XX}(\mathrm{d}) .{ }^{112}$ In this argument, the US position found support from the EU as well. The EU stated that the domestic and international instruments cited by India do not "point to any provisions that would require the specific action of imposing DCRs; neither has it identified specific provisions of the invoked laws and regulations that are complied with through DCRs." 113 The US and EU both cited further GATT and WTO reports to support their interpretation of compliance. The US cited a GATT era case, EEC-Parts and Components, wherein it was reasoned by the GATT Panel that compliance was meant "to enforce obligations" and not "to ensure the attainment of the objectives of laws and regulations." 114 The EU cited the panel report in Colombia-Ports of Entry wherein it was stated that "securing compliance" meant enforcement of obligations rather than ensuring attainment of the objectives of laws and regulations. ${ }^{115}$

As regards the interpretation of the term "necessary", the US cited observations by the Panel in US-Shrimp (Thailand) where the term "necessary" under Article XX(d) was interpreted as "something more than strictly making a contribution to." 116 The US took the position that the Indian DCR requirements only make an "indirect contribution to India's compliance with its commitments" and hence cannot be considered "necessary" within the meaning of Article XX(d). ${ }^{117}$ The US claimed that India has alternative policy options available to achieve its stated environmental goals instead of the DCRs, such as reducing or eliminating limitations on foreign direct investments in the solar PV sector, and secondly, reducing import tariffs on solar cells and modules which would serve to encourage investment in manufacturing solar PV technology products in India and also to reduce the overall costs of solar energy products. ${ }^{118}$

\footnotetext{
108 See WTO Panel Report, supra note 1 at para. 7.286; and USTR, supra note 20 at para. 50.

${ }^{109}$ See WTO Panel Report, supra note 1 at para. 7.304; and USTR, Ibid.

${ }^{110}$ USTR, Ibid., at para. 52.

${ }^{111}$ USTR, supra note 49 at paras. $40-1$.

112 USTR, supra note 20 at para. 54.

${ }^{113}$ EU, supra note 6 at para. 67; and WTO, supra note 3 at para. 7.305.

${ }^{114}$ GATT Panel Report, EEC-Regulation on Imports of Parts and Components, 16 May 1990, GATT Doc. No. BISD 37S/132 [EEC-Parts and Components] at para. 5.17 cited by USTR, supra note 20 at para. 54; see also, USTR, supra note 49 at para. 41.

${ }^{115}$ WTO Panel Report, Colombia -Indicative Prices and Restrictions on Ports of Entry, 27 April 2009, WTO Doc. WT/DS366/R at para. 7.538 cited by EU, supra note 6 at para. 67.

${ }^{116}$ WTO Panel Report, US-Measure Relating to Shrimp from Thailand, 29 February 2008, WTO Doc.

WT/DS343/R at para. 7.188 cited by USTR, supra note 49 at para. 42.

${ }^{117}$ USTR, supra note 49 at para. 44.

${ }^{118}$ USTR, supra note 20 at paras. 73-5.
} 
The Panel in its analysis noted that India's explanations failed to demonstrate any direct effect of international instruments cited by India. ${ }^{119}$ The Panel was of the view that India's executive or legislative branch must still adopt "implementing actions" in order to implement India's international obligations into the domestic legal system. ${ }^{120}$ Referring to the Appellate Body's statement in Mexico-Taxes on Soft Drinks that in some legal systems of the WTO Members international rules may have direct effect within the domestic legal systems without the need for implementing legislation, the Panel held that this statement does not imply a distinction between the executive arm of the government taking implantation action as opposed to the legislative arm. ${ }^{121}$ Rather, the Panel understood the Appellate Body's observation to mean the automatic incorporation of international rules into the domestic legal system without any implementing instrument by any branch of the government. ${ }^{122}$ Based on this finding, the Panel held that India had failed to demonstrate that any of the international instruments cited had a "direct effect" in India, or that any of the instruments are rules for the purposes of its domestic legal system. ${ }^{123}$

Alluding to the previous panel decisions on the occurrence of the term "rules or regulations" in GATT Article XX(d), the Panel stated that measures that advance the aims but do not enforce any obligations contained therein cannot qualify for the purpose of GATT Article XX(d). ${ }^{124}$ Hence, the Panel concluded that "laws or regulations" refer to legally enforceable rules of conduct under the domestic legal system of the WTO Member concerned, and do not include general objectives. ${ }^{125}$ The Panel accepted that the Electricity Act cited by India was law for the purposes of its interpretation, but that all other documents such as the National Electricity Policy, the National Electricity Plan, and the National Action Plan on Climate Change do not constitute legally enforceable rules of conduct. ${ }^{126}$ The Panel's overall conclusion was that the DCR measures maintained by India do not aid in securing compliance with laws and regulations (such as the Electricity Act) and therefore, India's claim under GATT Article XX(d) failed. ${ }^{127}$

\section{Exception under GATT Article XX(j)}

Another argument taken by India in defence of its DCRs was under Exception (j) of GATT Article XX. The relevant parts of Exception (j) provides for countries to adopte measures that are "Essential to the acquisition or distribution of products in general or local short supply."

Broken down to its very basics, this Exception allows countries to adopt measures to alleviate a short supply of essential materials. Whether or not this Exception applied in the present case turned upon the interpretation of the phrases "essential" and "short supply."

India took the argument that the market share of domestically-manufactured solar cells and modules was low. Hence, government intervention is needed to reduce dependency on foreign cells and modules. ${ }^{128}$ India referred to the post-World War II roots of Article XX(j) and

\footnotetext{
${ }^{119}$ WTO Panel Report, supra note 1 at para. 7.298.

${ }^{120}$ Ibid.

${ }^{121}$ Ibid., at para. 7.299 .

${ }^{122}$ Ibid., at para. 7.299-300.

${ }^{123}$ Ibid., at para. 7.301 .

${ }^{124}$ Ibid., at paras. 7.310, 7.330-32.

125 Ibid., at paras. 7.311.

${ }^{126}$ Ibid., at paras. 7.318 \& 7.322 .

${ }^{127}$ Ibid., at paras. 7.332-3.

${ }^{128}$ Ibid., at para. 7.189; see also, India's first written submission at para. 209 referred to by EU, supra note 6 at para. 47.
} 
acknowledged that the provision was meant to be applicable in exceptional circumstances only. However, the provision should be interpreted according to evolved circumstances. ${ }^{129}$ The crux of the Indian argument was that the expression "short supply" used within Article $\mathrm{XX}(\mathrm{j})$ was of a broad nature and it should be contextualized within the objectives of sustainable development, energy security, and environmental protection. ${ }^{130}$ India further took the argument that Article XX(j) not only deals with measures that are "essential" for acquiring products in short supply, but can also include measures that are "necessary" for addressing the "short supply" of products in question. ${ }^{131}$

In response to the Indian arguments, the US cited the Appellate Body in China-Raw Materials, which interpreted the expression "general or local short supply" as where a product is "available only in limited quantity" or "scarce". ${ }^{132}$ The US stated that this expression can mean both a shortage of supply in the international market without being in short supply locally, or a product that is readily available internationally but is in short supply locally within a country. ${ }^{133}$ The US used these alternative meanings and attacked India's arguments on both counts (i.e. India has failed to demonstrate whether solar cells or modules are in short supply internationally or locally). ${ }^{134}$ The US queried India's motive in light of India's admission that solar cells and modules are "adequately available" in the international market and yet India has not availed themselves of the opportunity of importing the products in "short supply" through imports. ${ }^{135}$ The EU, in its third party submission, also agreed with the US and stated that:

"[if] the products that are allegedly in short supply are solar cells and modules, it is... unclear how measures leading to restricting their importation could possibly alleviate the alleged shortage in supply, whether general or local. If anything, it will have the opposite effect." 136

Regarding the question of essentiality in Article $\mathrm{XX}(\mathrm{j})$, the US again referred to the Appellate Body's interpretation in China-Raw Materials. The Appellate Body had interpreted "essential” in that case as meaning “absolutely indispensable or necessary”. ${ }^{137}$ The US was of the view that, where a WTO Member is able to acquire and distribute the product in question, "it is difficult to envisage how a WTO-inconsistent measure to decrease availability of that product domestically could be 'essential' to the 'acquisition' or 'distribution' of that product." 138 The US observed that DCRs that discriminate against imports would increase difficulties in the acquisition or distribution of a product in short supply by limiting the sources of "supply". Hence, adopting such measures would be "antithetical" to the aims of Article XX(j). ${ }^{139}$ The US suggested stockpiling of solar cells and modules by India and elimination of DCRs as GATT-consistent alternatives to forestalling

\footnotetext{
${ }^{129}$ See WTO Panel Report, supra note 1 at para. 7.231; see also, India's first written submission at paras. 209-12 referred to by EU, supra note 6 at para. 47.

${ }^{130}$ See WTO Panel Report, supra note 1 at para. 7.231; see also India's first written submission at paras. 221-2 referred to by EU, supra note 6 at para. 48.

${ }^{131}$ See WTO Panel Report , supra note 1 at para. 7.239; see also India’s second written submission at paragraph 62 referred to by USTR, supra note 49 at para. 34 .

${ }^{132}$ WTO Appellate Body Report, China-Measures related to the Exportation of Various Raw Materials, 30 January 2012, WTO Doc. No. WT/DS395/AB/R [China-Raw Materials] at para. 325 cited by USTR, supra note 20 at para. 36; see also, WTO, supra note 2 at paras. 7.203-4.

${ }^{133}$ See WTO Panel Report, supra note 1 at para. 7.221; see also, USTR, supra note 20 at para. 36.

${ }^{134}$ Ibid.

${ }^{135}$ See reference to India's First Written Submission at paras. 233 and 236 referred to by USTR, supra note 20 at para. 37.

${ }^{136}$ EU, supra note 6 at para. 51.

${ }^{137}$ WTO Appellate Body Report, supra note 132 at para. 326 cited by USTR, supra note 20 at para. 38.

${ }^{138}$ USTR, supra note 20 at para. 38.

${ }^{139}$ Ibid.
} 
any "short supply". ${ }^{140}$ The US rounded off its argument on the Indian use of Article XX(j) by noting that Article XX(j) does not "sanction the use of WTO-inconsistent measures" to achieve government policy objectives when governments can easily acquire the products in question through alternative means. ${ }^{141}$

The Panel found that India failed in demonstrating the DCRs are justified under GATT Article XX(j). ${ }^{142}$ In reaching this conclusion, the Panel interpreted the expression "products in general or local short supply" to mean a scenario where quantity of available supply of a particular product does not meet the demand in a geographical area. ${ }^{143}$ The Panel stated that adopting India's interpretation of the expression "products in general or local short supply" would mean "products in general or local short production" and while the Panel agreed with India's argument that supply and production may be intrinsically linked, these two words are not interchangeable. ${ }^{144}$ The Panel also responded to India's alternative argument that lack of domestic manufacturing capacity establishes that a product is in short supply. ${ }^{145}$ The Panel said that India has neither pointed out to what constitutes lack of domestic manufacturing capacity, nor indicated what constitutes "sufficient” manufacturing capacity. ${ }^{146}$

Additionally, the Panel held that the term "products in general or local short supply" do not extend to products that are at risk of becoming in short supply. ${ }^{147}$ The Panel further explained that, if the concept of risk was to be included in the interpretation of "products in general or local short supply", then only "imminent" risks of such shortage should be permissible. ${ }^{148}$ The Panel in its analysis referred to the Appellate Body's interpretation in China-Raw Materials where the words "to prevent... critical shortages" in GATT Article XI: 2(a) were interpreted to include measures adopted to alleviate or reduce an existing critical shortage, as well as preventive or anticipatory measures adopted to pre-empt an imminent critical shortage. ${ }^{149}$ The word "imminent" was interpreted as something "soon to happen" by the Panel. ${ }^{150}$ On this point, the Panel noted out that India had not informed of any impending shortage of solar cells and modules in the world market prior to the dispute. ${ }^{151}$

Hence, the Panel found that that the risk of solar cells and modules becoming in short supply in India does not amount to solar cells and modules being "products in general or local short supply" within the meaning of Article XX(j). ${ }^{152}$ The next part of the article analyses the dispute and its effects on development of renewable energy sector in light of the Panel's decision.

\section{ANALYSIS}

The arguments made by the US and India should not be considered in isolation. The arguments themselves are a manifestation of deeper issues with the entire system of

\footnotetext{
${ }^{140}$ USTR, supra note 49 at para. 35.

${ }^{141}$ Ibid., at para. 37; and USTR, supra note 20 at para. 43.

${ }^{142}$ See WTO Panel Report, supra note 1 at paras. 7.264-5.

${ }^{143}$ Ibid., at paras. 7.207, 7.224-5, and 7.234.

${ }^{144}$ Ibid., at paras. 7.224.

145 Ibid., at paras. 7.226.

146 Ibid.

${ }^{147}$ Ibid., at paras. 7.237, 7.243, and 7.248-50.

${ }^{148}$ Ibid., at paras. 7.255-57.

${ }^{149}$ Ibid., at para. 7.257.

${ }^{150}$ Ibid., at para. 7.260.

${ }^{151}$ Ibid., at para. 7.262.

${ }^{152}$ Ibid., at para. 7.264-5.
} 
government support to fledgling industries. Successive Indian governments have consistently maintained a strong focus on foreign investment and enhancement of domestic industrial capacity. The JNNSM is an indicator that Indian governments wish to not only promote renewable energy projects to meet domestic demand for electricity, but also wish to marry this particular aim with the objective of enhancing domestic manufacturing of solar cells, modules, and other apparatus for use in Solar PV technology. Hence, we have the Indian Government expressing its intent to appeal the decision of the panel.

This article was written immediately after the announcement of the panel's decision in India-Solar Cells. With the availability of the text of the decision, we can see that the decision is close in letter and spirit to the Canada-Renewable Energy/Feed in Tariff case, at least where the extent of Article III: 8 derogation is concerned. The panel is obviously in a better position to rule on the merits of the arguments taken by the parties. However, with the benefit of hindsight, we take this opportunity to discuss the deeper issue of the trade interests of developing countries versus those of developed countries.

Whenever a trade dispute involving the environment, renewable energy products, or even environmental conservation policies of WTO Members becomes the subject of a WTO dispute settlement proceeding, we see commentators and analysts speculating on the legal rights of the disputants and interpretations of the parties. However, when we look carefully at the source of the problem, we can easily see that there is not enough specificity in the WTO law of subsidies, namely, that even though statutory language is framed prohibitively, it realistically allows nothing. The question, then, is how developing countries can pursue policies that are WTO-compliant and environmental-friendly. It is clear that existing WTO rules, in their present state, are unsuited for the attainment of this goal.

The US has conveniently taken the argument that it does not oppose India's efforts to pursue environmental aims through renewable energy projects. In fact, it claims that the Indian DCRs are actually counterproductive, as they restrict market access and result in the impediment of Indian measures to install solar PV projects. However, what the US ignores (or chooses not to accept) is the fact that the Indian measures are not just about environmental aims; they are about domestic industrial advancement, creation of jobs, and economic activity as well. These are aims that a heavily-populated, developing country with a significant population living below the poverty line like India simply cannot ignore. Viewed from this perspective, the DCR measures serve a dual purpose: economic progress and environmental protection through sustainable energy generation.

The obvious aim of the DCRs is to create domestic providers of solar PV products in the Indian market. This has clear benefits for the Indian economy, the foremost being that fullydeveloped solar PV industries would be able to compete with international suppliers, providing flow-on benefits for solar PV technology users due to induced price- and qualitybased competition. This competition can also spur technology innovation and even technology collaboration, which is a win-win scenario for any developing country facing environmental challenges.

Unfortunately, the GATT/WTO framework does not look kindly at incentivization policies such as DCRs. Ha-Joon Chang, for example, highlights the particular example of the ASCM and the TRIMS Agreement as effectively outlawing many policies and measures that several developed countries themselves adopted in their industrial advancement. ${ }^{153}$ Even more

\footnotetext{
${ }^{153}$ See generally, for e.g., Ha-Joon CHANG, Kicking Away the Ladder: Development Strategy in a Historical Perspective, $1^{\text {st }}$ ed (London: Anthem Press, 2002).
} 
unfortunate is the fact that, while we can indulge in academic debate on the merits and demerits of the WTO multilateral trading system, these problems cannot simply be resolved through democratic dispensation in the form of a legislative proposal to reform the WTO system. Meanwhile, India-Solar Cells and its predecessor Canada-Renewable Energy/Feed in Tariff will certainly not be the last cases involving a clash of environmental, trade, and domestic policy concerns. When looked at from the lens of Canada-Renewable Energy/Feed in Tariff, India has no doubt breached WTO law. But India, as a highly-populated developing country with a growing need for energy security, must be understood from its own perspective. India explained its perspective in the initial stages of the dispute settlement process by using words such as "energy security, ensuring ecologically sustainable growth, and ensuring sustainable development." The Panel claimed that it will assess the WTO-consistency of such measures while taking into account the policy rationale presented by India if they are legally relevant. ${ }^{154}$ However, results of the decisions in the aforementioned cases show little doubt that the WTO rules, as framed, cannot allow several types of support measures that can potentially be used to develop renewable energy industries.

Environmental groups and some industry groups will accuse the WTO of having an antienvironment bias. Such groups will point to earlier cases such as China-Rare Earths, China-Raw Materials, US-Shrimp and US_Gasoline in order to bolster their arguments. The challenge of balancing trade interests with other, often conflicting, aims of environmental conservation and domestic industrial capacity building will very likely lead to further trading disputes between WTO Members. The decisions highlighted above show that the results of these decisions would almost always be decided in advance. This underscores the need for change in the existing WTO approach. However, the WTO dispute settlement is itself constrained by the various agreements under the GATT/WTO framework. Aaron Cosbey aptly terms the WTO as "absolutely the wrong place to address issues of law where there is no international consensus on what the law should say." 155

If incentivisation is the only way a developing country can foster growth in an area it wishes to develop, then this will surely give rise to more cases where the conflict between the TRIMS Agreement and GATT Article III: 4 is the central subject. The problem is, however, even amongst the WTO Members themselves there is no clear agreement on how to determine violations of the TRIMS and GATT Article III: 4. This is illustrated through the divergence of views that emerged during the Panel proceedings. Brazil, for example, advocated an approach which grants primacy to GATT over the TRIMS Agreement. According to Brazil, claims similar to India-Solar Cells and Canada-Renewable Energy/Feed in Tariff must be resolved by fully examining the claims under GATT 1994 before considering TRIMS. ${ }^{156}$ The EU, on the other hand, considers the TRIMS Illustrative List along with Articles 2.1 and 2.2 of the TRIMS Agreement to be more specific in nature, enableing simplified decision-making instead of the open-ended assessments under GATT Article III. ${ }^{157}$ Japan and Canada disagree with the notion of specificity forwarded by the EU. Canada viewed TRIMS-specific nature limited only to the trade-related investment measures, while Japan favours an approach based on conduct of the past Panels that have dealt with TRIMS and GATT Article III: 4 together in disputes. ${ }^{158}$ The Panel, in its response, highlighted that past panels have reached different conclusions on the matter and that, in India-Solar Cells, the central issue is not about which

\footnotetext{
${ }^{154}$ Summarized in Paragraphs 7.17 of the Panel report; see also WTO Panel Report, supra note 1 at para. 7.19.

155 Aaron COSBEY, "Renewable Energy Subsidies and the WTO: The Wrong Law and the Wrong Venue” Global Subsidies Initiative (19 June 2011), online: International Institute for Sustainable Development <https://www.iisd.org/gsi/news/renewable-energy-subsidies-and-wto-wrong-law-and-wrong-venue> at 3.

${ }^{156}$ See WTO Panel Report, supra note 1 at para. 7.45.

${ }^{157}$ Ibid.

${ }^{158}$ Ibid.
} 
agreement is more specific or which one of the instruments should be considered first. Rather, it is about whether the DCR measure become inconsistent with GATT Article III: 4 if it fell within Paragraph 1(a) of the TRIMS Illustrative List. ${ }^{159}$ While the Panel offered its own view on the sequence of application (favouring the start of the analysis through Article 2.2 of the TRIMS), there is no guarantee that this analysis by the Panel provides a cogent and a workable template for a developing country to construct an incentivisation regime that is WTO-compliant. This is because the next panel confronted with a similar dispute might not follow the Panel in India-Solar Cells case. Considering India-Solar Cells and CanadaRenewable Energy/Feed in Tariff and then comparing them with the earlier cases that debated the TRIMS Agreement's specific relationship with GATT Article III: 4 reveals ambiguity and vagueness that only makes rules in this area of WTO law more archaic (see Table 1 below).

Table 1 - Comparison of Cases Dealing With GATT Article III: 4 and the TRIMs

\begin{tabular}{|c|c|c|}
\hline Case & $\begin{array}{c}\text { Paragraph } \\
\text { Reference }\end{array}$ & Panel's Decision \\
\hline Indonesia-Autos & Para 14.63 & $\begin{array}{l}\text { TRIMs Agreement was deemed to be "more } \\
\text { specific" than the GATT 1994. Hence the TRIMs } \\
\text { claims was examined first. }\end{array}$ \\
\hline Canada-Autos & Para 10.63 & $\begin{array}{l}\text { Panel expressed doubt on whether TRIMs } \\
\text { Agreement is more specific than the relevant GATT } \\
1994 \text { provisions. Analysis should be started on the } \\
\text { basis of GATT. }\end{array}$ \\
\hline India-Autos & Para 7.157 & Same as above. \\
\hline $\begin{array}{l}\text { Canada-Renewable } \\
\text { Energy/Feed in Tariff }\end{array}$ & Para 7.70 & $\begin{array}{l}\text { Since the TRIMs Agreement deals directly and } \\
\text { specifically in detail with the challenged aspects of } \\
\text { the measures at issue, therefore, the analysis should } \\
\text { begin from TRIMs }\end{array}$ \\
\hline
\end{tabular}

The effect of the lack of clarity in the area (compounded by the artificiality of the case-bycase approach) means that in the forseeable future, WTO Members (particularly developing countries) attempting to develop domestic industrial capacity will run into conflict with their WTO commitments. In other words, if developing countries comply with WTO commitments, any policy incentivising use of local production and are doomed from the start. Here, the observation that government intervention (e.g. subsidies) for renewable energy is a necessity in practically all countries seeking to promote renewable energy becomes particularly relevant. ${ }^{160}$ We must bear in mind that government intervention in developing new sectors of the economy is not just subsidy-based, but also spans a much wider spectrum of activities. Feed-in tariffs or guaranteed long term rates of power purchase are a time-tested method in attracting development and investment in the power generation sector. Therefore, the understanding of the term "government intervention: should not be limited to DCRs, but must also encompass measures like feed-in tariffs without which no renewable energy project will ever take off the ground.

Critics of such an approach conveniently ignore the historical development trajectory taken by developed countries. Such critics may also claim that, regardless of the outcome of the

\footnotetext{
${ }^{159}$ Ibid., at para. 7.46 .

${ }^{160}$ Pal, supra note 17 at 128; see also, Stokes, supra note 19 at 495 and discussion in Part III.
} 
dispute between India and the US on solar subsidies, the result will be increased use of renewable energy. Therefore, they claim that the argument that this decision impedes penetration of renewable energy is invalid. In response to this critique, we must adopt a broader approach to the issue of subsidies and incentives. If we look behind the triggers and motivators behind the dispute, the deeper issue is revealed. Whether or not the use of renewable energy will increase regardless of the outcome is not the real issue. Rather, the real issue is whose renewable energy products will be used. The US is trying to protect its industry interests by citing WTO law, while India is trying to promote the use of its domesticallymanufactured renewable energy products and to create jobs in the economy. Furthermore, we must also consider the fact that subsidies for renewable energy projects on the basis of import only will not interest a highly-populated developing country like India. In order to enhance penetration of renewable energy products, governments encourage the establishment of domestic manufacturing simultaneously with renewable energy projects with several aims in mind, such as job creation, promoting environmentally-friendly power generation, and reduced foreign exchange spending on imports. China had earlier followed a similar strategy in the wind power sector. This is evident from the fact that China not only managed to increase its installed wind capacity from 2599 Megawatts in 2006 to 44,733 Megawatts in 2010, but also simultaneously developed domestic manufacturing capacity in the sector as well. In 2004, 82\% of all wind power generation equipment installed in China was of foreign origin. This subsequently transitioned to $90 \%$ domestically-manufactured equipment used for all new wind power projects by $2010 .{ }^{161}$ According to latest data available from the World Wind Energy Association, China added 33 Gigawatts of new capacity in the wind energy sector in 2015, representing an overall market share of $51.8 \% .{ }^{162}$ China accomplished this growth on the back of subsidies, incentives, and the inward diversion of critical inputs, allowing Chinese industries to meet domestic demand while developing an export-oriented strategy in the wind power sector.

Along the way, we see that the US kept on challenging China's support measures in the WTO (most notable amongst these challenges are the China-Rare Earths, China-Raw Materials, China-Measures Concerning Wind Power Equipment cases). In all of the cases mentioned here, China "lost" and had to roll back its programmes. However, by the time the disputes were resolved through the WTO dispute settlement system, the incentives generated through inward diversion of resources and/or incentivisation had already done the trick for China. ${ }^{163}$ The net result is that Chinese wind turbine industries are now globally- and nationally-competitive. In addition to allowing China to conserve foreign exchange, these competitive industries allow China to engage an abundance of its labour resources. The cheaper price of domestically-manufactured components enable greater penetration of renewable energy products than what would be possible under the direct import model. This is clearly evident from the example of China's experience with its wind energy sector and from China's increased solar panel manufacturing (in 2015, China's solar capacity was 43.2

\footnotetext{
${ }^{161}$ ICTSD, “US Proclaims Victory in Wind Power Case; China Ends Challenged Subsidies” Bridges (8 June 2011), online: ICTSD <http://www.ictsd.org/bridges-news/bridges/news/us-proclaims-victory-in-wind-powercase-china-ends-challenged-subsidies>; see also, GHORI, supra note 48 at 132-3; Umair GHORI, “An Epic Mess: 'Exhaustible Natural Resources' and the Future of Export Restraints after the China-Rare Earths Decision” (2015) 16 (2) Melb. J. Int. Law 398 at 418-20.

162 World Wind Energy Association, “The World Sets New Wind Installations Record: 63,7 GW New Capacity In 2015” (10 February 2016), online: WWEA <http://www.wwindea.org/the-world-sets-new-wind-installationsrecord-637-gw-new-capacity-in-2015/>.

${ }^{163}$ For a detailed analysis of the China-Rare Earths decision and its effects on export restraints, see GHORI, supra note 161 at 425.
} 
Gigawatts. This is projected to reach 140 Gigawatts by 2020). ${ }^{164}$ Furthermore, according to one estimate, the corresponding power cost generated by China's solar power projects will fall by $38 \%$ by year 2020, leading to lowered costs and increased affordability of solar power projects. ${ }^{165}$ These compelling facts show that there is a strong nexus between domestic manufacturing and achievement of higher penetration of renewable energy generation which enables realization of environmental protection goals. Any developing country that is facing environmental challenges and therefore, desires pursuit of power generation through renewable energy cannot do so simply on the basis of imports (as the US, EU, and Japan are claiming in India-Solar Cells). Such a country must develop a domestic sector that can compete with imports leading to reduced prices of solar cells and modules instead.

\section{IV. “REVERSE PERMISSIBILITY”}

With the analysis of the preceding Part IV of the article, it is manifestly evident that the US is challenging the Indian DCRs because they incentivise purchasing of locally-manufactured solar panels and modules. WTO law is fast becoming more of an obstacle to development and the trade in environmentally-friendly technologies. It appears that the only way out for “defiant” developing countries, such as China and India, is firstly to adopt WTO-inconsistent policies (which any astutue reader of history of global trade knows is the route adopted by developed countries themselves in the their path to industrialization and economic development) and secondly, to discontinue these policies if challenged in the WTO.

Obviously the current state of affairs cannot continue for long. For one, it challenges the integrity of the WTO system; and secondly, it is becoming more and more a form of organised thuggery by the developed countries against many developing countries that wish to lay foundations of competing industrial sectors. Although reform is inevitable, the question which confronts the environmental groups, industry stakeholders, and WTO Members is the form which it will take. Cosbey cites Dani Rodrik's argument that incentivization should be permissible if the proposed activities are classified as "new". ${ }^{166}$ Cosbey also summarizes Rodrik's arguments that if the aim of the incentivization programme is to support activities that lead to economic growth, then it becomes important to distinguish between state support for existing sectors, those that are "genuinely new", and those which face several barriers to new activities. ${ }^{167}$ Additionally, the support extended to the new sectors must be subject to a sunset clause. ${ }^{168}$ While these proposals certainly sound good on paper, executing them is an entirely different game altogether.

We know for a fact that the WTO system is based on years of extended multilateral trade negotiations that resulted in the Marrakesh Agreement. We also know that until these underlying multilateral agreements are amended and changed, the dispute settlement system will keep churning out decisions like the Canada-Renewable Energy/Feed-in Tariff and India-Solar Cells cases simply because the dispute settlement panels and the Appellate Body are constrained to rule according to the agreements concluded by the WTO Members. While

\footnotetext{
${ }^{164}$ Richard MARTIN, “China is on an Epic Solar Power Binge” MIT Technology Review (22 March 2016), online: MIT Technology Review <https://www.technologyreview.com/s/601093/china-is-on-an-epic-solarpower-binge/>.

${ }^{165}$ Feifei SHEN, “China’s Solar Prices Could Fall 38 Percent by 2020, Become Competitive With Coal” Bloomberg (23 May 2016), online: Bloomberg <http://www.bloomberg.com/news/articles/2016-05-23/china-ssolar-prices-can-fall-38-become-competitive-with-coal>.

${ }^{166}$ Cosbey, supra note 155 at 3.

167 Ibid.

${ }^{168}$ Ibid.
} 
the Doha Round remains indefinitely bogged down and with negotiators reluctant to take on any additional agenda items, the chances for amendment of the multilateral agreements falling within the aegis of the Marrakesh Agreement appear slim.

An alternative approach that may be possible, given the constraints of the Doha Round and the ticking time bomb of climate change, is to incorporate an agreed departure from the GATT/WTO norms limited to environmental protection. Within the context of subsidies and support measures, this can be termed as the "Reverse Permissibility" approach. Under this approach, instead of using open and abstract language which essentially prohibit all types of state subsidies, WTO Members can adopt a "reverse" stance by concluding an agreed departure. The agreed departure identifies a narrow range of measures that are expressly permissible. These permissible measures can, for example, be limited to development of new sectors in an economy that can help achieve environmental conservation aims. Furthermore, in order to execute plans for the development of new sectors, DCRs could be made permissible while measures such as quantitative restrictions can remain prohibited. Clearly specifying permissible subsidy measures will not only minimize the need of WTO Members to resort to the dispute settlement mechanism, but also enable developing countries, in particular, to draft policies around the core of permissible subsidy measures. Such an approach automatically cures the timing argument between GATT Article III: 4 and provisions of the TRIMS Agreeement. ${ }^{169}$ Reverse Permissibility in environment-related state support measures will also enhance transparency in an otherwise ambiguous area of GATT/WTO Framework. This means that the WTO Members clearly know which measures are permissible and which measures are not.

The next step involves special and differential treatment combined with a limited time grant to countries desiring the establishment of new domestic renewable energy sectors. At the end of the specified period, these countries would be required to undertake measures to gradually liberalize their economies and allow open competition within them. This can be done through a mandatory sunset clause. The resulting competition would allow for a much more open playing field for both domestic and foreign suppliers. The end result, from an environmental perspective, would be the lowering of costs (a result that is demonstrated through projected tariff reduction in China of solar power by year 2020) and increased market penetration of renewable energy technologies within the developing country markets. The major obstacle to adopting such a course of action will come from developed countries, whose vested trade interests have prompted actors such as the EU, Japan, and the US to challenge any measures that may pose a competitive threat. The ASCM and the TRIMS Agreement are couched in terms that allow little room for manoeuvering as far as developing countries are concerned. Therefore, any efforts to negotiate an agreed departure from GATT/WTO norms in order to accommodate the environmental objectives within the WTO framework must also take into account the impact of the ASCM and the TRIMS Agreement.

In constructing the reverse permissibility model, we must also consider an interesting argument that may flow from the reasoning in the Canada-Renewable Energy/Feed in Tariff and India-Solar Cells cases. This argument flows from the scenario where the government of a WTO Member procures domestically-produced solar cells and modules as part of a government procurement plan so that Article III: 8(a) derogation may be availed. The procured cells and modules can then be supplied to SPDs with the precondition that they be used in order to avail feed-in tariffs and other incentives. This may provide a way out for developing countries in a similar position to India. However, it will not at all be surprising if this "way out" is barred by a WTO dispute settlement process as well.

169 See discussion in the preceding part of this article. 
Problems also stem from conflicting understandings of what "governmental purpose" or "public function" amounts to when determining government procurement. The Panel in India-Solar Cells noted the treatment of the issue in Canada-Renewable Energy/Feed in Tariff, where the Appellate Body was of the view that that the phrase "products purchased for governmental purposes" in Article III:8(a) "refers to what is consumed by the government or what is provided by government to recipients in the discharge of its public functions", with the scope of such functions determined on a case-by-case basis. ${ }^{170}$ The Appellate Body also noted that there must be a rational relationship between the purchased product and the governmental function being discharged. ${ }^{171}$ This means that it becomes essential for the term "governmental function" to be interpreted because it provides the causal link between what is and is not permissible under GATT Article III: 4 and TRIMS. Unfortunately, the GATT/WTO Framework is silent on this term. Furthermore, the artificiality of the case-by-case approach in dispute settlement means that, even if the Panel or Appellate Body affixes a meaning to the term in question, there is no guarantee that the same meaning will be fully applicable in the next dispute involving GATT Article III: 4, III: 8, and TRIMS. A quick perusal of Paragraphs 7.157-7.162 of the India-Solar Cells Panel report demonstrates a conflict between the disputants' respective understanding on what is meant by governmental function and how that fits in with government procurement.

Thus, if a country follows a particular governance system which may combine several governmental purposes and public functions, will the WTO law bypass those governmental functions? There is no clear answer to this question. However, what is abundantly clear from decisions such as India-Solar Cells is that no developing country can develop a competing sector in renewable energy without state support; which, unfortunately, by the decision in India-Solar Cells has been declared illegal under the WTO. It is exactly this shortcoming that is cured by adopting a "reverse permissibility" approach which aims to adopt a more specific approach to the issue of state support. Under the suggested approach, if a developing country wishes to establish a "new" sector of development which contributes to goals such as environmental conservation and sustainable power generation through renewable energy, then it should be permissible for states to extend support. Furthermore, the suggested approach specifies clear meanings for terms such as governmental purposes and public functions. Doing so may serve to plug the gaps left by the GATT/WTO Framework, which often causes confusion for policymakers and government officials when constructing WTO-compliant policies. The execution of reverse permissibility can be done through a multilateral approach similar to the GATT Enabling Clause that allowed preferential treatment to be extended for developing countries by avoiding the GATT MFN obligations. The first possible step could be consolidation of all relevant GATT/WTO decisions into a separate agreement followed by the second step that takes the form of an agreed departure. This is a difficult proposition because negotiating an agreed departure may run into roadblocks, given that the industrial interests of several developed countries militate against giving any incubation room for competing industries to develop in the developing countries. However, this solution is clearly necessitated because WTO law as it stands currently promotes a pure import model as opposed to domestic capacity building, which developing countries seem to be interested in for promoting greater penetration of renewable energy technologies in their power sectors.

\footnotetext{
${ }^{170}$ WTO Panel Report, supra note 1 at para. 7.156.

${ }^{171}$ Ibid.
} 